\title{
Literaturverzeichnis zum Beitrag Scheuerlein/Köckerling
}

1 Keller HW, Wolters U, Hülser R, et al: Die Entwicklung der kolorektalen Tumorchirurgie in den letzten 20 Jahren. Zentralbl Chir 1993;118:122-126.

2 Abulafi AM, Williams NS: Local recurrence of colorectal cancer: The problem, mechanisms, management and adjuvant therapy. Br J Surg 1994;81:7-19.

3 Fielding P: Colorectal carcinoma: Mesorectal excision for rectal cancer (editorial). Lancet 1993;341:471-472.

4 Heald RJ, Husband EM, Ryall RDH: The mesorectum in rectal cancer surgery - the clue to pelvic recurrence? Br J Surg 1982;69:613-616.

5 Gall FP, Hermanek P: Wandel und derzeitiger Stand der chirurgischen Therapie des kolorektalen Karzinoms. Chirurg 1992;63:227-234.

6 Gall FP, Hermanek P: Update of the German experience with local excision of rectal cancer. Surg Oncol Clin North Am 1992;1:99-109.

7 Hermanek P: Klinische Pathologie des Rektumkarzinoms. Chir Gastroenterol 1995;11:304-308.

8 Krook JE, Moertel CE, Gunderson LL, et al: Effective surgical adjuvant therapy for high-risk rectal carcinoma. N Engl J Med 1991;324:709-715.

9 Swedish Rectal Cancer Trial: Improved survival with preoperative radiotherapy in resectable rectal cancer. N Engl J Med 1997;336:980-987.

10 Moynihan B: The surgical treatment of cancer of the sigmoid flexure and rectum. Surg Gynecol Obstet 1908;6:463-466.

11 Gall FP, Hermanek FP: Die erweiterte Lymphknotendissektion beim Magen- und colorectalen Carcinom - Nutzen und Risiken. Chirurg 1988;59:202-210.

12 Goldberg S, Klas JV: Total mesorectal excision in the treatment of rectal cancer: A view from the USA. Semin Surg Oncol 1998;15:87-90.

13 Wiig JN, Carlsen E, Søreide O: Mesorectal excision for rectal cancer: A view from Europe. Semin Surg Oncol 1998;15:78-86. 
14 Enker WE, Laffer UT: Standardisierte Operationen gewährleisten optimale Therapie beim Rektumkarzinom. Situation in den Vereinigten Staaten; in Büchler MW, Heald RJ, Maurer CA, Ulrich B (Hrsg): Rektumkarzinom: Das Konzept der Totalen Mesorektalen Exzision. Karger, Basel, 1998, pp 112-121.

15 Stelzner F: Radical resection with autonomic nerve preservation and lymph node dissection techniques in lower rectal cancer surgery (letter). Langenbecks Arch Surg 1999;384:405-406.

16 Girona J: Das Mesorektum in der Chirurgie des Rectumcarcinoms. Chirurg 1993;64:549-551.

17 Stolte M, Lauer E: Praxis der kolorektalen Chirurgie: Vielfach immer noch inadäquate Resektionen. Leber Magen Darm 1992;22:145-149.

18 Winkler R: Geschichte der Rektumchirurgie; in Reifferscheid M (Hrsg):

Rektumkarzinom. Stuttgart, Thieme, 1983, pp 1-5.

19 Curti G, Maurer CA, Büchler MW: Colorectal carcinoma: Is lymphadenectomy useful? Dig Surg 1998;15:193-208.

20 Kocher T: Über Radicalheilung des Krebses. Dtsch Z Chir 1880;13:134.

21 Kraske P: Zur Exstirpation hochsitzender Mastdarmkrebse. Langenbecks Arch Klin Chir 1886;33:563.

22 Krönlein D: Über die Resultate der Operation des Mastdarmcarcinoms. Langenbecks Arch Klin Chir 1900;61:309.

23 Schloffer H: Die Laparotomie im Dienste der Rektumexstirpation. Bruns Beitr Klin Chir 1904;42:396.

24 Miles WE: A method of performing abdomino-perineal excision for carcinoma of the rectum and of the terminal portion of the pelvic colon. Lancet 1908;ii:1812-1813.

25 Clogg HS: Cancer of the colon. A study of 72 cases. Lancet 1908;ii:1007-1012.

26 Jamieson JK, Dobson JF: The lymphatics of the colon. Ann Surg 1909;50:1077-1090.

27 Dukes CE: The classification of cancer of the rectum. J Pathol Bacteriol 1932;35:323332.

28 Gabriel W, Dukes C, Bussey H: Lymphatic spread in cancer of the rectum. Br J Surg $1935 ; 23: 395-423$.

29 Dixon CF: Anterior resection for malignant lesions of the upper part of the rectum and lower part of the sigmoid. Trans Am Surg Assoc 1948;66:175.

30 Sauer I, Bacon HE: Influence of lateral spread of cancer of the rectum on radicability of operation and prognosis. Am J Surg 1951;81:111. 
31 Stearns MW, Deddish MR: Five-year results of abdominopelvic lymph node dissection for carcinoma of the rectum. Dis Col Rectum 1959;2:169-173.

32 Barnes JP: Physiologic resection of the right colon. Surg Gynecol Obstet 1952;94:722-726.

33 Cole WH, Packard D, Southwick HW, et al: Carcinoma of the colon with special reference to prevention of recurrence. JAMA 1959;155:1549-1553.

34 Turnbull RB, Kyle K, Watson FR, et al: Cancer of the colon: The influence of the notouch isolation technique on survival rates. Ann Surg 1967;166:420-427.

35 Rohen JW: Topographische Anatomie; Aufl 8. Stuttgart, Schattauer, 1987, p 372.

36 Miles WE: Pathology of spread of cancer of rectum and its bearing upon surgery of cancerous rectum. Surg Gynecol Obstet 1931;52:350-359.

37 Hermanek P: Evolution and pathology of rectal cancer. World J Surg 1982;6:502-509.

38 Block IR, Enquist IF: Lymphatic studies pertaining to local spread of carcinoma of the rectum in female. Surg Gynecol Obstet 1961;112:41-46.

39 Miscusi G, Masori L, Dell' Anna A, et al: Normal lymphatic drainage of the rectum and anal canal revealed by lymphoscintigraphy. Coloproctology 1987;9:171-174.

40 Dworak O: Staging und Metastasenstrassen unter besonderer Berücksichtigung des Mesorektums; in Büchler MW, Heald RJ, Maurer CA, Ulrich B (Hrsg):

Rektumkarzinom: Das Konzept der Totalen Mesorektalen Exzision. Karger, Basel, 1998, pp 27-32.

41 Lehnert T, Herfarth C: Grundlagen und Wert der Lymphadenektomie beim colorectalen Carcinom. Chirurg 1996;67:889-899.

42 Hohenberger W, Hermanek P Jr, Hermanek P Sen, et al: Decision-making in curative rectum carcinoma surgery. Onkologie 1992;15:209-220.

43 Köckerling F, Reymond MA, Altendorf-Hofmann A, et al: Influence of surgery on metachronous distant metastases and survival in rectal cancer. J Clin Oncol 1998;16:324-329.

44 Hohenberger W: The effect of specialization or organization of rectal cancer surgery; in Søreide O, Norstein J (eds): Rectal Cancer Surgery. Berlin, Springer, 1997, pp 353363.

45 Påhlmann L: Surgery for rectal cancer: The relationship between treatment volume and results; in Søreide O, Norstein J (eds): Rectal Cancer Surgery. Berlin, Springer, 1997, pp 364-370. 
46 McArdle CS, Hole D: Impact of variability among surgeons on postoperative morbidity and mortality and survival. BMJ 1991;302:1501-1505.

47 Hermanek P, Wiebelt $\mathrm{H}$, Staimmer D, et al: Prognostic factors of rectum carcinomaexperience of the German Multicentre Study SGCRC (German Study Group ColoRectal Carcinoma). Tumori 1995; 81(suppl 3):60-64.

48 Ranbargar KR, Johnston WD, Chang JC: Prognostic significance of surgical perforation of the rectum during abdominoperineal resection for rectal carcinoma. Am J Surg 1982;143:186-188.

49 Slanetz CAJR: The effect of inadvertent intraoperative perforation on survival and recurrence in colorectal cancer. Dis Colon Rectum 1984;27:792-797.

50 Holm T, Johannson H, Cedermark B, et al: Influence of hospital- and surgeon-related factors on outcome after treatment of rectal cancer with or without preoperative radiotherapy. Br J Surg 1997;84:657-663.

51 Simons AJ, Ker R, Groshen S, et al: Variations in treatment of rectal cancer: The influence of hospital type and caseload. Dis Colon Rectum 1997;40:641-646.

52 McLeod RS: Symposion on rectal cancer: 2. Local recurrence after surgery for rectal cancer. Can J Surg 1997;40:353-357.

53 Porter GA, Soskolne CL, Yakimets WW, et al: Surgeon-related factors and outcome in rectal cancer. Ann Surg 1998;227:157-167.

54 Zirngibl H, Husemann B, Hermanek P: Intraoperative spillage of tumor cells in surgery for rectal cancer. Dis Colon Rectum 1990;33:610-614.

55 Phillips RK, Hittinger R, Blesovsky L, et al: Local recurrence following 'curative' surgery for large bowel cancer: I. The overall picture. Br J Surg 1984;71:12-16.

56 Patel SC, Tovee EB, Langer B: Twenty five-years' experience with radical surgical treatment of carcinoma of the extraperitoneal rectum. Surgery 1977;82:460-465.

57 Cohen AM: Surgical considerations in patients with cancer of the colon and rectum. Sem Oncol 1991;18:381-387.

58 Ault GW: A technique for cancer isolation and extended dissection for cancer of the distal colon and rectum. Surg Gynecol Obstet 1958;106:467-477.

59 Cole WH, Roberts SS, Strehl FW: Modern concepts of cancer of the colon and rectum. Cancer 1966;19:1347-1358.

60 Wiggers T, Jeekel J, Arends JW, et al: No-touch isolation technique in colon cancer: A controlled prospective trial. Br J Surg 1988;75:409-415. 
61 MacKeigan JM, Ferguson JA: Prophylactic oophorectomy in colorectal cancer in premenopausal patients. Dis Colon Rectum 1979;22:401-405.

62 Cutait R, Lesser ML, Enker WE: Prophylactic oophorectomy in surgery for large bowel cancer. Dis Colon Rectum 1983;26:6-11.

63 Graffner HOL, Alm POA, Oscarson JEA: Prophylactic oophorectomy in colorectal carcinoma. Am J Surg 1983;146:233-235.

64 Morrow M, Enker WE: Late ovarian metastases in carcinoma of the colon and rectum. Arch Surg 1984;119:1385-1388.

65 O'Brien PH, Newton BB, Metcalf JS, et al: Oophorectomy in women with carcinoma of the colon and rectum. Surg Gynecol Obstet 1981;153:827-830.

66 Abcarian H: Operative treatment of colorectal cancer. Cancer 1992;70:1350-1354.

67 Prohaska JV, Nelson S, Evans SO: Radical surgery in advanced carcinoma of intraabdominal organs. Arch Surg 1956;73:681-685.

68 Gall FP, Tonak J, Altendorf A: Multivisceral resections in colorectal cancer. Dis Colon Rectum 1987;30:337-341.

69 Köckerling F, Schug C, Hohenberger W: Multiviszerale Resektionen beim Kolonkarzinom - Grenzen und Techniken; in Beger HG, Rühland D, Siewert JR (Hrsg): Kolon-/Rektumchirurgie, Postgraduiertenkurs Kolon-/Rektumkarzinom (DGVC). 116. Kongreß der Deutschen Gesellschaft für Chirurgie. Singen, DCS, 1999, pp 44-50.

70 Köckerling F, Gall FP: Chirurgische Standards beim Rectumcarcinom. Chirurg 1994;65:593-603.

71 Junginger T, Mentges B: Radikalitätsprinzipien bei der Operation des Coloncarcinoms. Langenbecks Arch Chir (Kongreßbericht) 1987;372:481-486.

72 Runkel N: Standardoperationen beim primären Kolonkarzinom; in Buhr HJ, Runkel N (Hrsg): Operationskurs Kolorektales Karzinom. Heidelberg, Barth, 1998, pp 53-59.

73 Meyer HJ: Onkologische Chirurgie des Coloncarcinoms. Langenbecks Arch Chir (Kongreßbericht) 1997;suppl II:159-163.

74 Germer CT, Isbert C: Kurative Standardresektion beim Rektumkarzinom; in Buhr HJ, Runkel N (Hrsg): Operationskurs Kolorektales Karzinom. Heidelberg, Barth, 1998, pp $61-69$.

75 Gordon PH: Malignant neoplasms of the rectum; in Gordon PH, Nivatwongs S (eds): Principles and Practice of Surgery for the Colon, Rectum and Anus. St. Louis, Quality Medical Publishing, 1999, pp 719-807. 
76 Gilbertsen VA: Adenocarcinoma of the rectum: Incidence and locations of recurrent tumor following present-day operations performed for cure. Ann Surg 1960;151:340348.

77 Morson BC, Vaughan EG, Bussey HJR: Pelvic recurrence after excision of rectum for carcinoma. BMJ 1963;II:13-18.

78 Moossa AR, Ree PC, Marks JE, et al: Factors influencing local recurrence after abdominoperineal resection for cancer of the rectum and rectosigmoid. Br J Surg 1975;62:727-730.

79 Rosen L, Veidenheimer MC, Coller JA, et al: Mortality, morbidity, and patterns of recurrence after abdominoperineal resection for cancer of the rectum. Dis Colon Rectum 1982;25:202-208.

80 Theile DE, Cohen JR, Evans EB, et al: Pelvic recurrence after curative resection for carcinoma of the rectum. Aust N Z J Surg 1982;52:391-394.

81 Localio SA, Eng K, Coppa GF: Abdominosacral resection for midrectal cancer. Ann Surg 1983;198:320-324.

82 Pheils MT, Chapuis PH, Newland RC, et al: Local recurrence following curative resection for carcinoma of the rectum. Dis Colon Rectum 1983;26:98-102.

83 Pollett WG, Nicholls RJ: The relationship between the extent of distal clearance and survival and local recurrence rates after curative anterior resection for carcinoma of the rectum. Ann Surg 1983;198:159-163.

84 Rich T, Gunderson LL, Lew R, et al: Patterns of recurrence of rectal cancer after potentially curative surgery. Cancer 1983;52:1317-1329.

85 Påhlmann L, Glimelius B: Local recurrences after surgical treatment for rectal carcinoma. Acta Chir Scand 1984;150:331-335.

86 Pilipshen SJ, Heilweil M, Quan SHQ, et al: Patterns of pelvic recurrence following definitive resections of rectal cancer. Cancer 1984;53:1354-1362.

87 Williams NS, Johnston D: Survival and recurrence after sphincter saving resection and abdominoperineal resection for carcinoma of the middle third of the rectum. Br J Surg 1984;71:278-282.

88 Adloff M, Arnaud JP, Schloegel M, et al: Factors influencing local recurrence after abdominoperineal resection for cancer of the rectum. Dis Colon Rectum 1985;28:413415 .

89 Leff EI, Shaver JO, Hoexter B, et al: Anastomotic recurrences after low anterior resection. Dis Colon Rectum 1985;28:164-167. 
90 McDermott FT, Hughes ESR, Pihl E, et al: Local recurrence after potentially curative resection for rectal cancer in a series of 1,008 patients. Br J Surg 1985;72:34-37.

91 Balslev IB, Pedersen M, Teglbjaerg PS, et al: Postoperative radiotherapy in Dukes' B and C carcinoma of the rectum and rectosigmoid. Cancer 1986;58:22-28.

92 Danzi M, Ferulano GP, Abate S, et al: Survival and locations of recurrence following abdomino-perineal resection for rectal cancer. J Surg Onc 1986;31:235-239.

93 Heimann TM, Szporn A, Bolnick K, et al: Local recurrence following surgical treatment of rectal cancer. Dis Colon Rectum 1986;29:862-864.

94 Malmberg M, Graffner H, Ling L, et al: Recurrence and survival after anterior resection of the rectum using the end to end anastomotic stapler. Surg Gynecol Obstet 1986;163:231-234.

95 Carlsson U, Lasson Å, Ekelund G: Recurrence rates after curative surgery for rectal carcinoma, with special reference to their accuracy. Dis Colon Rectum 1987;30:431434 .

96 Colombo PL, Scotti Foglieni CL, et al: Analysis of recurrence following curative low anterior resection and stapled anastomoses for carcinoma of the middle third and lower rectum. Dis Colon Rectum 1987;30:457-464.

97 Stockholm Rectal Cancer Study Group: Short-term preoperative radiotherapy for adenocarcinoma of the rectum. Am J Clin Oncol 1987;10:369-375.

98 Athlin L, Bengtsson NO, Stenling R: Local recurrence and survival after radical resection of rectal carcinoma. Acta Chir Scand 1988;154:225-229.

99 Feil W, Wunderlich M, Kovats E, et al: Rectal cancer: Factors influencing the development of local recurrence after radical anterior resection. Int J Colorect Dis 1988;3:195-200.

100 Michelassi F, Block GE, Vannucci L, et al: A 5- to 21-year follow-up and analysis of 250 patients with rectal adenocarcinoma. Ann Surg 1988;208:379-389.

101 Hojo K, Sawada T, Moriya Y: An analysis of survival and voiding, sexual function after wide iliopelvic lymphadenectomy in patients with carcinoma of the rectum, compared with conventional lymphadenectomy. Dis Colon Rectum 1989;32:128-133.

102 Moriya Y, Hojo K, Sawada T, et al: Significance of lateral node dissection for advanced rectal carcinoma at or below the peritoneal reflection. Dis Colon Rectum 1989;32:307-315. 
103 Rubbini M, Vettorello GF, Guerrera C, et al: A prospective study of local recurrence after resection and low stapled anastomosis in 183 patients with rectal cancer. Dis Colon Rectum 1990;33:117-121.

104 Amato A, Pescatori M, Butti A: Local recurrence following abdominoperineal excision and anterior resection for rectal carcinoma. Dis Colon Rectum 1991;34:317322.

105 Braun J, Pfingsten F, Schippers E, et al: Rektumkarzinom - Ergebnisse kontinenzerhaltender Resektionen. Leber Magen Darm 1992;2:59-70.

106 Clemmesen T, Sprechler M: Recording of patients with colorectal cancer on a database: Results and advantages. Eur J Surg 1994;160:175-178.

107 Tumorregister Chirurgische Universitätsklinik Erlangen, pers. Mitt. 1997.

108 Fändrich F, Schröder D, Saliveros E: Long-term survival after curative resection for carcinoma of the rectum. J Am Coll Surg 1994;178:271-276.

109 Graffunder S: Die laparoskopische abdominoperineale Rektumexstirpation. Frühe onkologische Ergebnisse einer Multicenterstudie. Friedrich-Alexander-Universität Erlangen-Nürnberg, Dissertation 1999.

110 Karavias T, Häring R: Chirurgie des Lokalrezidivs; in Izbicki JR, Wilker DK, Schweiberer L (Hrsg): Das kolorektale Karzinom und seine Präkanzerosen. Berlin, De Gruyter, 1990, pp 407-419.

111 Heald RJ: Anterior resection of the rectum; in Fielding LP, Goldberg SM (eds): Rob and Smith's Operative Surgery: Surgery of the Colon, Rectum and Anus. London, Butterworth-Heinemann, 1993, p 456.

112 Konerding MA, Heintz A, Huhn P, et al: Rektumkarzinom - Optimierung durch Kenntnis der Anatomie unter besonderer Berücksichtigung des Mesorektums. Zentralbl Chir 1999;124:413-417.

113 Heald RJ: The 'holy plane' of rectal surgery. J R Soc Med 1988;81:503-508.

114 Wiig JN, Heald RJ: Rectal and pelvic anatomy with emphasis on anatomical layers; in Søreide O, Norstein J (eds): Rectal Cancer Surgery. Berlin, Springer, 1997, pp 117122.

115 McFarlane JK, Ryall RDH, Heald RJ: Mesorectal excision for rectal cancer. Lancet 1993;341:457-460.

116 Heald RJ, Ryall RDH: Recurrence and survival after total mesorectal excision for rectal cancer. Lancet 1986;i:1479-1482. 
117 McAnena OJ, Heald RJ, Lockhart-Mummery HE: Operative and functional results of total mesorectal excision with ultra-low anterior resection in the management of carcinoma of the lower one-third of the rectum. Surg Gynecol Obstet 1990;170:517521.

118 Karanjia ND, Schache DJ, Heald RJ: Function of the distal rectum after low anterior resection for carcinoma. Br J Surg 1992;79:114-116.

119 Heald RJ, Karanjia ND: Results of radical surgery for rectal cancer. World J Surg 1992;16:848-857.

120 Carlsen E, Schlichting E, Guldvog, et al: Effect of the introduction of total mesorectal excision for the treatment of rectal cancer. Br J Surg 1998;85:526-529.

121 Heald RJ, Moran BJ, Ryall RD, et al: Rectal cancer: The Basingstoke experience of total mesorectal excision, 1978-1997. Arch Surg 1998;133:894-899.

122 Leo E, Belli F, Andreola S, et al: Total rectal resection, mesorectum excision, and coloendoanal anastomosis: A therapeutic option for the treatment of low rectal cancer. Ann Surg Oncol 1996;3:336-343.

123 Enker WE: Total mesorectal excision - the new golden standard of surgery for rectal cancer. Ann Med 1997;29:127-133.

124 Arenas RB, Fichera A, Mhoon D, et al: Total mesorectal excision in the surgical treatment of rectal cancer: A prospective study. Arch Surg 1998;133:608-611.

125 Hida J, Masayuki Y, Takamasa M, et al: Lymph node metastases detected in the mesorectum distal to carcinoma of the rectum by the clearing method: Justification of total mesorectal excision. J Am Coll Surg 1997;184:584-588.

126 Matzel KE, Stadelmaier U, Mühldorfer S, et al: Continence after colorectal reconstruction following resection: Impact of level of anastomosis. Int J Colorectal Dis 1997;12:82-87.

127 Isbister WH: Personal view: Basingstoke revisited. Aust N Z J Surg 1990;60:243-246.

128 Heald RJ: Basingstoke replies. Aust N Z J Surg 1991;61:91-93.

129 Maurer CA, Büchler MW: Mesorektale Resektion beim Rektumkarzinom: Hypothese oder kontrollierter Benefit? In Beger HG, Rühland D, Siewert JR (Hrsg): Kolon/Rektumchirurgie, Postgraduiertenkurs Kolon-/Rektumkarzinom (DGVC). 116. Kongreß der Deutschen Gesellschaft für Chirurgie. Singen, DCS, 1999, pp 58-63.

130 Hohenberger W, Schick CH, Gohl J: Mesorectal lymph node dissection: Is it beneficial? Langenbecks Arch Surg 1998;383:402-408. 
131 Köhler L, Eypasch E, Paul A, et al: Myths in management of colorectal malignancy. Br J Surg 1997;84:248-251.

132 Cummings BJ: Symposion on rectal cancer: 3. The case for adjuvant radiotherapy for rectal cancer. Can J Surg 1997;40:358-362.

133 Willett CG, Hagan M, Daley W, et al: Changes in tumor proliferation of rectal cancer induced by preoperative 5-fluorouracil and irradiation. Dis Colon Rectum 1998;41:6267.

134 O'Connell MJ, Martenson JA, Wieand HS, et al: Improving adjuvant therapy for rectal cancer by combining protracted-infusion fluorouracil with radiation therapy after curative surgery. N Engl J Med 1994;331:502-507.

135 Hohenberger W, Schick CH, Merkel S: Laterale Lymphknotendissektion beim Rektumkarzinom - ein onkologisches Prinzip? In Beger HG, Rühland D, Siewert JR (Hrsg): Kolon-/Rektumchirurgie, Postgraduiertenkurs Kolon-/Rektumkarzinom (DGVC). 116. Kongreß der Deutschen Gesellschaft für Chirurgie. Singen, DCS, 1999, pp 64-67.

136 Hida J, Yasutomi M, Fujimoto K, et al: Comparison between the Japanese general rules and the TNM system in the regional lymph node classification of carcinoma of the colon. J Am Coll Surg 1996;183:611-615.

137 Moreira LF, Hizuta A, Iwagaki, et al: Lateral lymph node dissection for rectal carcinoma below the peritoneal reflection. Br J Surg 1994;81:293-296.

138 Hida J, Yasutomi M, Fujimoto M, et al: Does lateral lymph node dissection improve survival in rectal carcinoma? Examination of node metastasis by the clearing method. J Am Coll Surg 1997;184:475-480.

139 Quirke P, Durdey P, Dixon MF, et al: Local recurrence of rectal adenocarcinoma due to inadequate surgical resection. Lancet 1986;2:996-999.

140 Enker WE, Heilweil ML, Hertz RE, et al: En bloc pelvic lymphadenectomy and sphincter preservation in the surgical management of rectal cancer. Ann Surg 1986;203:426-433.

141 Liu SY, Wang YN, Zhu WQ, et al: Total pelvic exenteration for locally advanced rectal carcinoma. Dis Colon Rectum 1994;37:172-174.

142 Di Matteo G, Mascagni D, Lentini A, et al: Advances in rectal cancer surgery. Dis Colon Rectum 1994;37(suppl):S50-S53. 
143 Yamakoshi H, Ike H, Oki S, et al: Metastasis of rectal cancer to lymph nodes and tissues around the autonomic nerves spared for urinary and sexual function. Dis Colon Rectum 1997;40:1079-1084.

144 Moriya Y, Kenichi S, Takayuki A, et al: Importance of extended lymphadenectomy with lateral node dissection for advanced lower rectal carcinoma. World J Surg 1997;21:728-732.

145 Mori T, Takahashi K, Yasuno M: Radical resection with autonomic nerve preservation and lymph node dissection techniques in lower rectal cancer surgery and its results: The impact of lateral lymph node dissection. Langenbecks Arch Surg 1998;383:409415.

146 Suzuki K, Muto T, Sawada T: Prevention of local recurrence by extended lymphadenectomy for rectal carcinoma. Surg Today Jpn J Surg 1995;25:795-801.

147 Michelassi F, Block GE: Morbidity and mortality of wide pelvic lymphadenectomy for rectal adenocarcinoma. Dis Colon Rectum 1992;35:1143-1147.

148 Glass RE, Ritchie JK, Thompson HR, et al: The results of surgical treatment of cancer of the rectum by radical resection and extended abdominosacral lymphadenectomy. $\mathrm{Br}$ J Surg 1985;72:599-601.

149 Enker WE, Thaler HT, Craner ML, et al: Total mesorectal excision in the operative treatment of carcinoma of the rectum. J Am Coll Surg 1995;181:335-346.

150 Maas CP, Moriya Y, Steup WH, et al: Radical and nerve-preserving surgery for rectal cancer in the Netherlands: A prospective study on morbidity and functional outcome. Br J Surg 1998;85:92-97.

151 Enker WE: Potency, cure, and local control in the operative treatment of rectal cancer. Arch Surg 1992;127:1396-1402.

152 Hojo K, Vernava AM, Sugihara K, et al: Preservation of urine voiding and sexual function after rectal cancer surgery. Dis Colon Rectum 1991;34:532-539.

153 Enker WE, Havenga K, Thaler HT, et al: Total mesorectal excision with pelvic autonomic nerve preservation in the operative treatment of rectal carcinoma; in Søreide O, Norstein J (eds): Rectal Cancer Surgery. Berlin, Springer, 1997, pp 220_ 243.

154 Maurer CA, Renzulli P, Meyer JD, et al: Rektumkarzinom - Optimierung durch partielle oder totale Mesorektumentfernung. Zentralbl Chir 1999;124:428-435.

155 Taat CW, Maas CP, Steup WH, et al: Surgical option in rectal cancer; in Søreide O, Norstein J (eds): Rectal Cancer Surgery. Berlin, Springer, 1997, pp 183-202 
156 Moriya Y: Importance of lymphatic spread; in Søreide O, Norstein J (eds): Rectal Cancer Surgery. Berlin, Springer, 1997, pp 153-164.

157 Moriya Y: Nerve-sparing surgery: Surgical neuroanatomy and techniques; in Søreide O, Norstein J (eds): Rectal Cancer Surgery. Berlin, Springer, 1997, pp 244-254.

158 Stelzner F: Chirurgie an den visceralen Abschlußsystemen. Stuttgart, Thieme, 1998.

159 Mori T: Reply (letter). Langenbecks Arch Surg 1999;384:407-408.

160 Harnsberger JR, Vernava AM, Longo WE: Radical abdominopelvic lymphadenectomy: Historic perspective and current role in the surgical management of rectal cancer. Dis Colon Rectum 1994;34:73-87.

161 McFarlane JK: Lateral node dissection - a critique; in Søreide O, Norstein J (eds): Rectal Cancer Surgery. Berlin, Springer, 1997, pp 255-263.

162 Gall FP: Die tiefe Rektumresektion - transabdominaler Zugang. Chirurg 1991;62:1-7.

163 Grinnell RS, Hiatt RB: Ligation of the inferior mesenteric artery at the aorta in resections for carcinoma of the sigmoid and rectum. Surg Gynecol Obstet 1952;94:526-34.

164 Bacon HE, Khubchandani IT: The rationale for aortoiliopelvic lymphadenectomy and high ligation of the inferior mesenteric artery for carcinoma of the left half of the colon and rectum. Surg Gynecol Obstet 1964;119:503-508.

165 Busuttil RW, Foglia RP, Longmire WP: Treatment of carcinoma of the sigmoid colon and upper rectum. Arch Surg 1977;112:920-923.

166 Bland KI, Polk HC: Therapeutic measures applied for the curative and palliative control of colorectal carcinoma. Surg Annu 1983;15:123-161.

167 Pezim ME, Nicholls RJ: Survival after high or low ligation of the inferior mesenteric artery during curative surgery for rectal cancer. Ann Surg 1984;200:729-733.

168 Rothenberger DA, Wong WD: Rectal cancer - adequacy of surgical management. Surg Annu 1985;17:309-336.

169 Surtees P, Ritchie JK, Phillips RKS: High versus low ligation of the inferior mesenteric artery in rectal cancer. Br J Surg 1990;77:618-621.

170 Corder AP, Karanjia ND, Williams JD, et al: Flush aortic tie versus selective preservation of the ascending left colic artery in low anterior resection for rectal carcinoma. Br J Surg 1992;79:650-652.

171 Sugarbaker PH, Corlew S: Influence of surgical techniques on survival in patients with colorectal carcinoma. Dis Colon Rectum 1982;25:545-557. 
172 Adachi Y, Inomata M, Miyazaki N, et al: Distribution of lymph node metastasis and level of inferior mesenteric artery ligation in colorectal cancer. J Clin Gastroenterol 1998;26:179-182.

173 Hida J, Yasutomi M, Maruyama T, et al: Indication for using high ligation of the inferior mesenteric artery in rectal cancer surgery. Dis Colon Rectum 1998;41:984991.

174 Mörschel M, Heintz A, Dienes HP, et al: Lymphknotendissektion, Stadienverschiebung und perioperatives Risiko beim Rectumcarcinom. Chirurg 1996;67:915-920.

175 Mörschel M, Heintz A, Dutkowski P, et al: Der Einfluß der Zahl der dissezierten Lymphknoten auf die Lokalrezidivrate rectaler Carcinome. Chirurg 1997;68:10231028.

176 Rumpelt HJ, Schmidt C, Störkel S: Lymphknotenstatus beim kolorektalen Karzinom. Pathologe 1992;13:269-275.

177 Hohenberger P, Schlag P, Kretzschmar U, et al: Das regionäre Lymphknotenrezidiv beim colorectalen Carcinom: Überlegungen zur Genese und Therapie auf der Basis angiographischer Befunde. Chirurg 1991;61:110-116.

178 Herfarth C, Hohenberger P: Lymphadenektomie bei der Primärtherapie colorectaler Carcinome. Chirurg 1989;60:139-147.

179 Enker WE, Laffer UT, Block GE: Enhanced survival of patients with colon and rectal cancer is based upon wide anatomic resection. Ann Surg 1979;190:350-360.

180 Haboubi NY, Clark P, Kaftan SM, et al: The importance of combining xylene clearance and immunohistochemistry in the accurate staging of colorectal cancer. J R Soc Med 1992;85:386-388.

181 Tagliacozzo S, Daniele GM, Accordino M: Extensive lymphadenectomy and longterm survival in right hemicolectomy for carcinoma. Ann Ital Chir 1992;63:175-183.

182 Tagliacozzo S, Tocchi A: Extended mesenteric excision in right hemicolectomy for carcinoma of the colon. Int J Colorect Dis 1997;12:272-275.

183 Adachi Y, Mori M, Matsushima T, et al: The distribution of lymph node metastases in right-sided colon cancer. J Clin Gastroenterol 1994;19:210-213.

184 Hida J, Yasutomi M, Maruyama T, et al: The extent of lymph node dissection for colon carcinoma: The potential impact on laparoscopic surgery. Cancer 1997;80:188192. 
185 Klupp J, Engels S, Junginger T: Einfluß der Lymphknotendissektion auf die Prognose des Kolonkarzinoms. Zentralbl Chir 1995;120:821-825.

186 Staniunas RJ, Schoetz DJ: Extended resections for carcinoma of colon and rectum. Surg Clin North Am 1993;73:117-129.

187 Bruch HP, Schwandner O, Schiedeck THK, et al: Actual standards and controversies on operative technique and lymph node dissection in colorectal cancer. Langenbecks Arch Surg 1999;384:167-175. 